\title{
Experimental study of accelerating early age concrete strength under elevated temperature, steaming, and chemical admixture addition of normal and high strength concrete
}

\author{
Suryawan Murtiadi ${ }^{1, *}$, Akmaluddin Akmaluddin $^{1}$, Buan Anshari ${ }^{1}$, and Suparjo Suparjo ${ }^{2}$ \\ ${ }^{1}$ Master Program of Civil Engineering, Post Graduate Program, University of Mataram, Indonesia. \\ ${ }^{2}$ Department of Civil Engineering, Faculty of Engineering, University of Mataram, Indonesia.
}

\begin{abstract}
Conventionally, curing is performed by moisturizing concrete periodically when the fresh concrete is still undergoing chemical reaction processes. This study is focused on early age concrete strength treated with special curing of early heating treatment and steaming. The addition of chemical accelerator and normal curing are also examined. Tests were conducted on normal and high strength concrete specimens. Treatments of the test specimens with steaming and early heating were carried out for 3 and 8 hours, respectively, at a temperature of about $70^{\circ} \mathrm{C}$. Test results showed that concrete compressive strengths gained in 3-days compared to 28-days under normal curing, chemical accelerator, steam curing, and elevated temperature curing were $39 \%, 50 \%, 64 \%$ and $59 \%$, respectively. While in 7-days were $66 \%, 75 \%, 80 \%$ and $83 \%$, respectively. And in $14-$ days were $87 \%, 91 \%, 93 \%$ and $93 \%$, respectively. For high-strength concrete, the compressive strengths gained in 3-days were $37 \%, 62 \%, 68 \%$ and $71 \%$, respectively. The strengths in 7-days were $65 \%, 77 \%, 83 \%$ and $82 \%$, respectively. And in 14-days were $85 \%, 89 \%, 90 \%$ and $93 \%$, respectively. Test results indicated that the additions of chemical accelerator, steam and elevated temperature curing in order to obtain the high early age concrete strengths are highly recommended.
\end{abstract}

\section{Introduction}

\subsection{Background}

Concrete is a very popular building material in the construction industry because of its strength to withstand high compressive forces. Concrete is an artificial conglomerate stone made essentially of water, cement, and aggregates. A chemical reaction takes place when the first mixed water and cement establish of paste surrounding all the individual piece of aggregates. This chemical reaction is called hydration when the heat is given off during the

\footnotetext{
* Corresponding author: s.murtiadi@unram.ac.id
} 
reaction as the cement hydrates. In order to achieve the designed properties of the mixture, concrete needs a curing to maintain an adequate moisture content during chemical reaction at early ages.

Curing begins immediately after placement and finishing so that the concrete may develop the desired strength and durability. Traditionally, curing is performed by moisturizing concrete periodically to reduce water loss due to evaporation and concrete hydration. This traditional method requires a relatively long maintenance time. However, in construction work, sometimes a concrete that has a high initial strength is needed to accelerate the time consumed during the whole construction. Special treatments of early age concrete to accelerate initial strength using steam curing have been used in several precast concrete industries $[1,2]$.

This study focused on early age concrete strength treated with special curing of early heating treatment and steaming. The effects of adding chemical accelerator on the compressive strength at an early age are also examined. The traditional curing of normal strength and high strength concrete specimens are also conducted as standard and comparator specimens. Tests were conducted in the Laboratory of Material and Structural, Department of Civil Engineering, Faculty of Engineering, University of Mataram.

\subsection{Literature review}

The heat of hydration is caused by the temperature raise that occurs when the cement reacts with water, expressed in calories/grams. Silicate and aluminate on the cement react with water into a solid adhesive material and form a hard mass. Hydration of cement is exothermic with an amount of heat released approximately 120 calories/gram. For the usual hot cement type, it varies between 37 calories/gram at $5^{\circ} \mathrm{C}$ to 80 calories/gram at $40^{\circ} \mathrm{C}$. For all types of cement in general about $50 \%$ of the total heat is released between 1 and 3 days, about $75 \%$ of the heat changes depend on the composition of the cement [3].

Concrete treatment is influenced by the temperature and moisture of the concrete itself. Therefore, concrete treatment not only affects the strength of the concrete but also affects the resistance of the concrete. The use of effective treatment methods depends on the type of material used, the type of construction and expected exposure of the concrete. There are two methods of concrete treatment based on the temperature used, i.e. normal treatment and maintenance at elevated temperature [4].

According to the Indonesian Standard accelerated curing is a treatment with highpressure steam, evaporation at atmospheric pressure, heating and moisturizing or other acceptable processes. These processes may be undertaken to accelerate concrete strength and reduce maintenance time [5]. The optimum temperature is in the range of $65^{\circ} \mathrm{C}$ to $80^{\circ} \mathrm{C}$. The use of lower temperatures requires a longer maintenance time but provides better strength [6].

Early age of concrete under various curing method and treatment have been done in the laboratory $[7,8]$. The investigation included the curing with elevated temperature. The comparison to normal treatment by moisturizing concrete specimens was then evaluated. Test results indicated that concrete compressive strengths of 3, 7, and 14 days were rapidly accelerated under elevated temperature. However, the 28 days concrete compressive strength slightly decreased.

The ground granulated blast-furnace slag has been used at the precast concrete factory for the purpose of durability improvement on the resistance of concrete product [9]. Ground granulated blast furnace slag is used under the maximum curing temperature of $70^{\circ} \mathrm{C}$ and deforming from 2.5 hours. The results indicated that high fluidity concrete has the capability to save labor in placement work and improve the working environment as well as improve concrete durability. Under 3 hours steams curing at $60^{\circ} \mathrm{C}$, the compressive 
strengths of concrete compare to 28 days compressive strength were $44 \%$ and $71 \%$ for the ages of 15 hours and 7 days, respectively.

A relationship between initial strength at early age of concrete calculated by Maturity Method and Arrhernius Law was evaluated using experiment investigation. The experiment use cube specimens of size $\varnothing 50 \times 100$ with various water-cement ratios of 30\%, 40\%, 50\% and exposed under curing temperatures variations of $10^{\circ} \mathrm{C}, 20^{\circ} \mathrm{C}, 30^{\circ} \mathrm{C}$. The accuracy of the prediction was different in each condition such as cement type, water-cement ratio, steam curing temperature, and material age [10]. By promoting cement hydration, raising steam curing temperature to $70^{\circ} \mathrm{C}$ could significantly increase initial compressive strength as well as the permeability of concrete specimens. However, it has several negative effects on the durability caused by surface resistivity and capillary absorption [11].

\section{Materials and experimental procedure}

\subsection{Materials}

Based on the examinations of fine and coarse aggregates, mixed design of the concrete specimens can be composed according to the Indonesian Standard [5]. Viscocrete $311 \mathrm{~N}$ has been used as a superplasticizer to produce high-strength concrete. In order to accelerate the early strength of specimens, SikaCim Accelerator is also added as a chemical addition. Portland cement type I has been used for all specimens. The mix proportion of $1 \mathrm{~m} 3$ concrete mixture can be seen in Table 1 as follow:

Table 1. Mix Proportion of $1 \mathrm{~m} 3$ Concrete

\begin{tabular}{|c|c|c|c|c|c|c|c|c|}
\hline \multirow{2}{*}{$\begin{array}{l}\text { Speci } \\
\text { mens }\end{array}$} & \multirow{2}{*}{$\begin{array}{c}\mathbf{f}^{\prime} \mathbf{c} \\
(\mathrm{MPa})\end{array}$} & \multirow[t]{2}{*}{$\mathbf{w} / \mathbf{c}$} & Water & Cement & $\begin{array}{c}\text { Fine } \\
\text { Aggregate }\end{array}$ & $\begin{array}{c}\text { Coarse } \\
\text { Aggregate }\end{array}$ & $\begin{array}{l}\text { Accel } \\
\text { erator }\end{array}$ & $\begin{array}{l}\text { Super } \\
\text { plasti } \\
\text { cizer }\end{array}$ \\
\hline & & & \multicolumn{6}{|c|}{ (kg) } \\
\hline $\mathrm{NN}$ & \multirow{2}{*}{30} & \multirow{2}{*}{0.45} & 225.00 & 500 & 565.46 & 906.54 & - & - \\
\hline NA & & & 185.63 & 500 & 565.46 & 906.54 & 79.20 & - \\
\hline $\mathrm{HN}$ & \multirow{2}{*}{50} & \multirow{2}{*}{0.30} & 225.00 & 750 & 551.46 & 761.54 & - & 2.48 \\
\hline HA & & & 185.63 & 750 & 551.46 & 761.54 & 79.20 & 2.48 \\
\hline
\end{tabular}

Where: $\quad \mathrm{NN}=$ Normal-strength concrete

$\mathrm{NA}=$ Normal-strength concrete with accelerator

$\mathrm{HN}=$ High-strength concrete

$\mathrm{HA}=$ High-strength concrete with accelerator

\subsection{Test specimens}

In this study, a $15 \times 15 \times 15 \mathrm{~cm}$ cube of both normal and high strength concrete specimens was prepared for compressive strength testing at ages 3, 7, 14 and 28 days, respectively. Specimens curing were performed under three conditions: normal curing, steam curing and elevated temperature curing. Specimens with an addition of chemical accelerator under normal curing also conducted for evaluation and comparison to the concrete compressive strength acceleration at early age. The numbers of test specimens are presented in Table 2. Its can be seen in the table that the total numbers of the test were 96 specimens. 
Table 2. Test Specimens

\begin{tabular}{|c|c|c|c|c|c|c|}
\hline \multirow{2}{*}{$\begin{array}{l}\text { Concrete } \\
\text { Strength }\end{array}$} & \multirow{2}{*}{ Curing } & \multicolumn{4}{|c|}{ Number of Specimens under Compressive Test } & \multirow{2}{*}{ Tota } \\
\hline & & 3 Days & 7 Days & 14 Days & 28 Days & \\
\hline \multirow{4}{*}{$\begin{array}{l}\text { Normal } \\
\text { Strength }\end{array}$} & Normal curing & 3 & 3 & 3 & 3 & 12 \\
\hline & Steam curing & 3 & 3 & 3 & 3 & 12 \\
\hline & $\begin{array}{c}\text { Elevated } \\
\text { temperature }\end{array}$ & 3 & 3 & 3 & 3 & 12 \\
\hline & Accelerator & 3 & 3 & 3 & 3 & 12 \\
\hline \multirow{4}{*}{$\begin{array}{l}\text { High } \\
\text { Strength }\end{array}$} & Normal curing & 3 & 3 & 3 & 3 & 12 \\
\hline & Steam curing & 3 & 3 & 3 & 3 & 12 \\
\hline & $\begin{array}{c}\text { Elevated } \\
\text { temperature }\end{array}$ & 3 & 3 & 3 & 3 & 12 \\
\hline & Accelerator & 3 & 3 & 3 & 3 & 12 \\
\hline \multicolumn{6}{|c|}{ Total Number of Specimens } & 96 \\
\hline
\end{tabular}

\subsection{Instrumentation and test procedure}

\subsubsection{Steam curing}

According to the Indonesian Standard [5], early age accelerated strength of concrete is a treatment with high-pressure steam, evaporation at atmospheric pressure, heating and moisturizing or other acceptable processes. Steam curing will increase the compressive strength of early age concrete and reduce maintenance time. Steam treatment can prevent rapid and irregular hydration processes with high temperatures, so concrete compressive strength can be quickly achieved and concrete pores can be avoided.

Treatment with steam curing has been carried out in this investigation by inserting the specimens into a steam room. Shown in Fig. 1, the tool used in this research is a steamer tool made from two pieces of a steamer connected together. Water was boiled in the first steamer and the steam heat was then distributed to the stowing specimens in the second steamer using heat resistant pipe. The time-temperature relationship of the steamer is given in Fig. 2 in which the following can be explained.

After \pm 2 hours of steaming, the steam room temperature begins to gradually raised. Further \pm 30 minutes the steam room reaches a temperature of $70^{\circ} \mathrm{C}$. Keep the steam room at this temperature for 3 hours before turning off the heater. Then the temperature begins to decrease and reaches the room temperature of $30^{\circ} \mathrm{C}$ within 30 minutes. After 1 hour of cooling, remove the specimens from the steam room, store it in a save place and then it is ready to be tested in due course. 

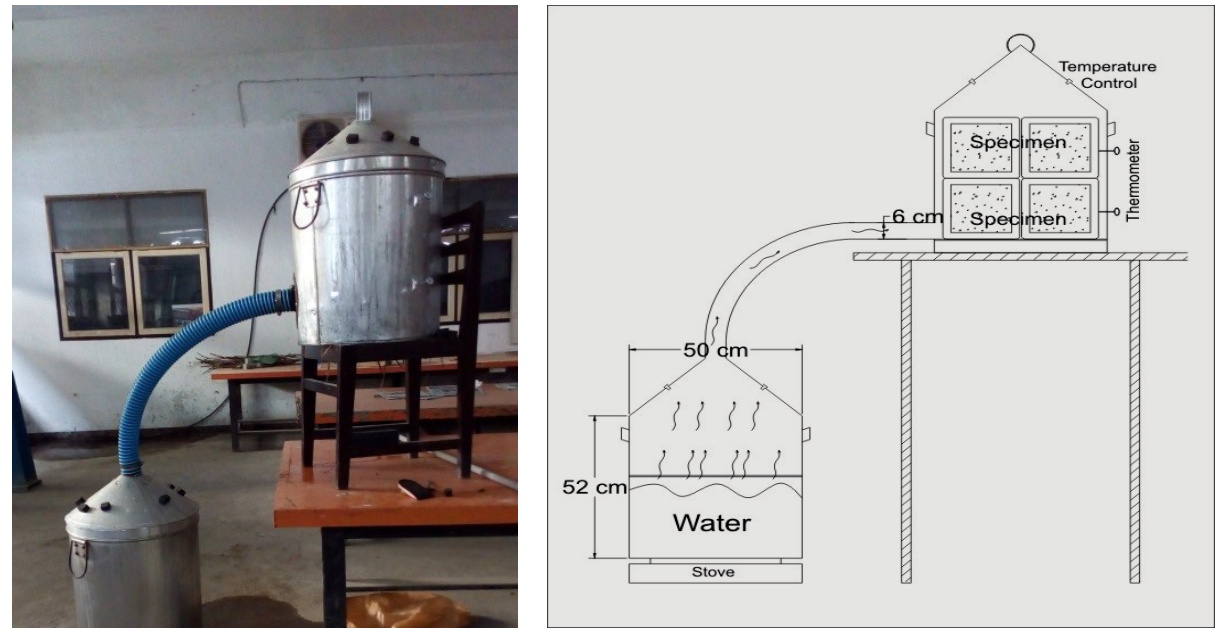

Fig. 1. Steamer tool

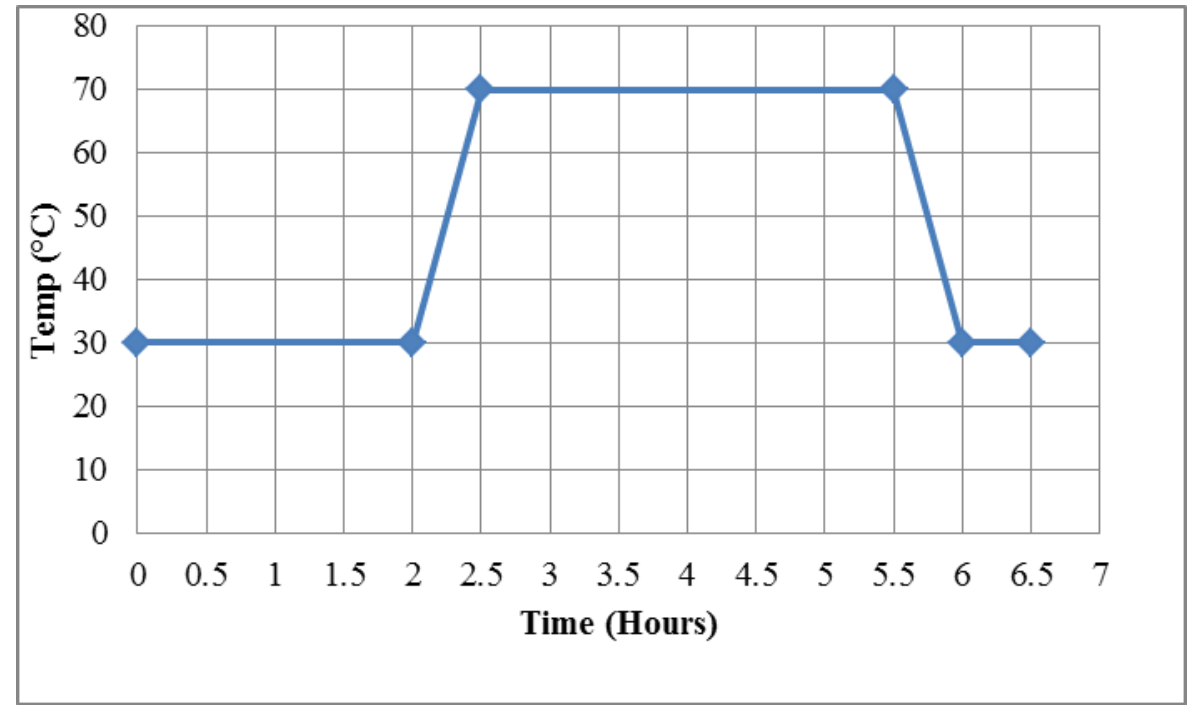

Fig. 2. Time - temperature of steamer

\subsubsection{Elevated temperature curing}

The hardened concrete specimens after final setting were removed from the casting and placed into a heating furnace. The heating furnace instrument (oven) can be seen in Fig. 3 . While Fig. 4 gives the curve of time versus temperature setting. The figure shows that the temperature has been held at $70^{\circ} \mathrm{C}$ under duration of 8 hours. After cooling, the specimens were removed from the furnace and kept in a save place before their compressive strength was tested in intended time. 


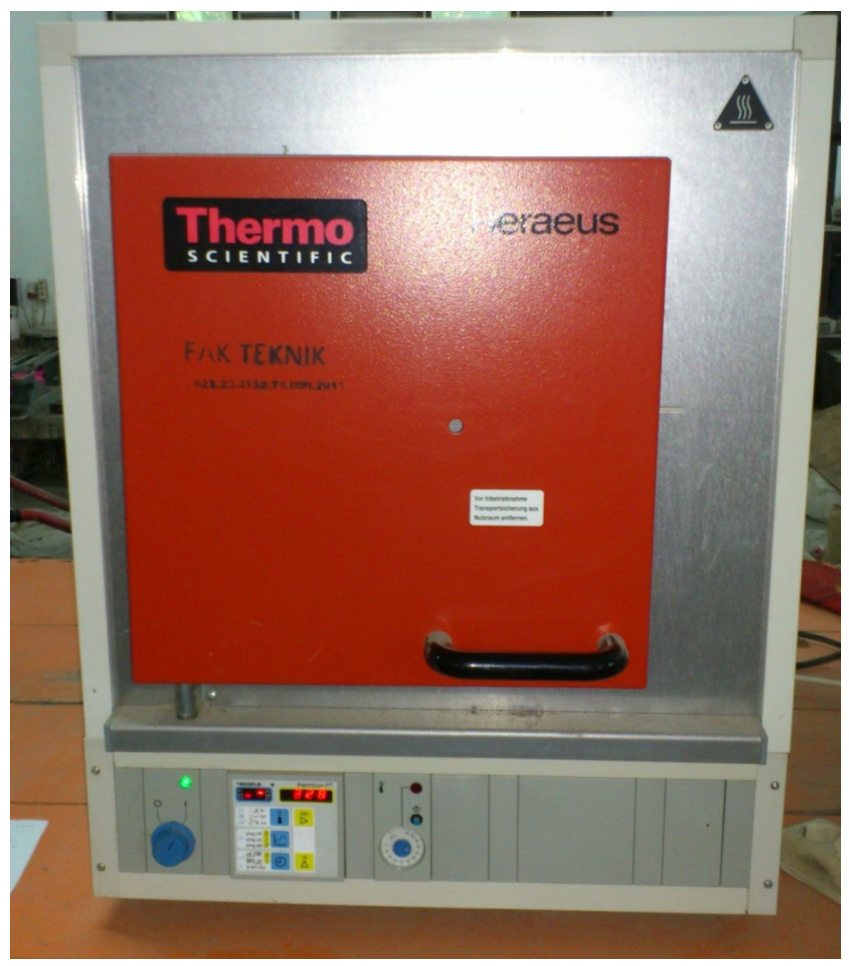

Fig. 3. Heating furnace instrument (oven)

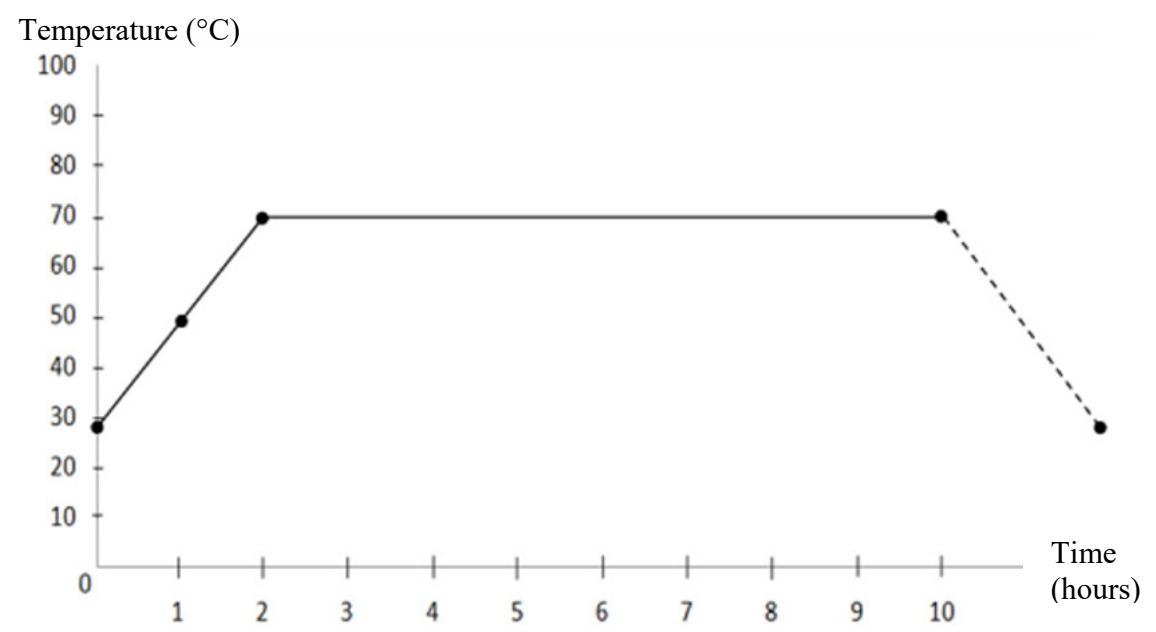

Fig. 4. Time - temperature of oven

\subsubsection{Normal curing}

Normal curing begins immediately after the concrete has hardened at the final setting which is generally at about 12-24 hours. Curing in concrete at early age has the purpose of ensuring the cement hydration process to proceed completely by maintaining an adequate moisture content and temperature conditions. This treatment will avoid shrinkage cracks on the surface and the desired quality of the concrete can be achieved. 
In this study, 48 specimens have been treated under normal curing including 24 specimens with chemical accelerator addition for early strength of normal and high strength concrete. Immediately after they were removed from the mould, the specimens are stored and submerged in a water tank. When the considered time arrived, the specimens are taken out of the water tanks, capped with very high strength sulphur compound and tested for the compressive strength investigation.

\section{Test results and discussions}

\subsection{Normal strength concrete}

Results of the compressive test presented in Table 3 for normal strength concrete and the normalized percentage of compressive strength to 28 days is given in Table 4. Furthermore, the percentage of high-strength concrete compressive test to 28 days is performed in Fig. 5.

Table 3. Compressive strength (MPa)

\begin{tabular}{|c|c|c|c|c|}
\hline \multirow{2}{*}{ Specimens } & \multicolumn{4}{|c|}{ Ages of specimens } \\
\cline { 2 - 5 } & 3 Days & 7 Days & 14 Days & 28 Days \\
\hline NN & 12.12 & 20.51 & 27.03 & 31.07 \\
\hline NA & 16.67 & 25.01 & 30.34 & 33.34 \\
\hline NS & 18.94 & 23.68 & 27.53 & 29.60 \\
\hline NT & 17.78 & 25.01 & 28.02 & 30.13 \\
\hline
\end{tabular}

Where: $\quad \mathrm{NN}=$ Normal strength concrete under normal curing

$\mathrm{NA}=$ Normal strength concrete with accelerator

$\mathrm{NS}=$ Normal strength concrete under steam curing

$\mathrm{NT}=$ Normal strength concrete under elevated temperature curing.

Table 4. Normalized percentage of normal concrete compressive test to 28 days

\begin{tabular}{|c|c|c|c|c|}
\hline \multirow{2}{*}{ Specimens } & \multicolumn{4}{|c|}{ Ages of specimens } \\
\cline { 2 - 5 } & 3 Days & 7 Days & 14 Days & 28 Days \\
\hline NN & $39 \%$ & $66 \%$ & $87 \%$ & $100 \%$ \\
\hline NA & $50 \%$ & $75 \%$ & $91 \%$ & $100 \%$ \\
\hline NS & $64 \%$ & $80 \%$ & $93 \%$ & $100 \%$ \\
\hline NT & $59 \%$ & $83 \%$ & $93 \%$ & $100 \%$ \\
\hline
\end{tabular}




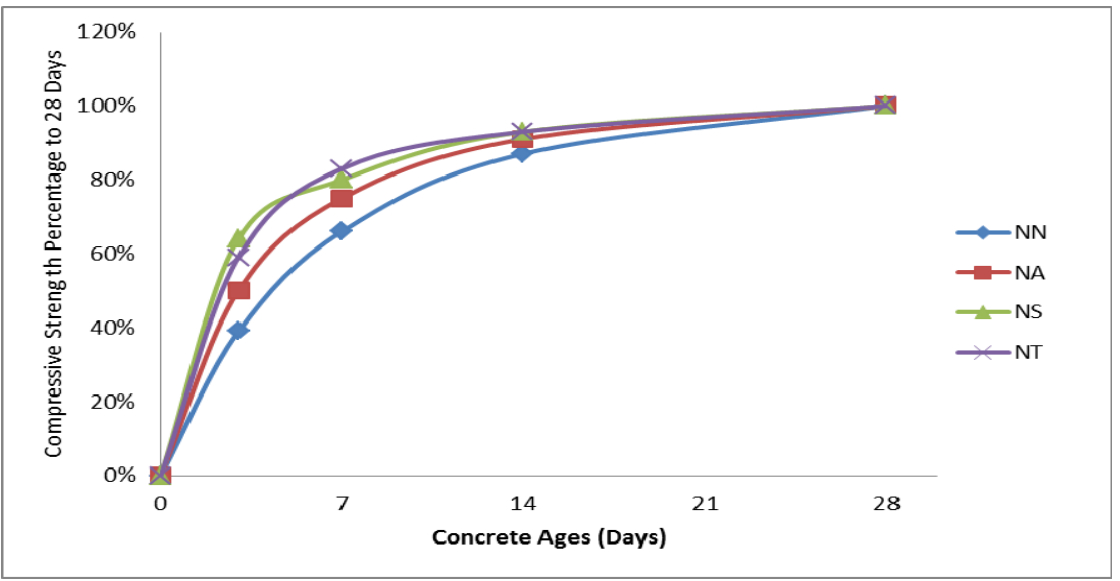

Fig. 5. Percentage of normal strength concrete compressive test to 28 days

Under normal curing, the value of concrete strength in 3, 7 and 14 days compared to 28 days were $39 \%, 66 \%$, and $87 \%$, respectively. The results show that the experimental results agree with the typical conventional normal strength concrete. In the age of 3 days, the specimen under steam curing has the highest accelerated concrete strength of $64 \%$. This indicates that the early concrete strength is accelerated by $165 \%$ compare to normal curing.

Concrete compressive strengths gained in 3-days compared to 28-days under normal curing, chemical accelerator addition, steam curing, and elevated temperature curing were $39 \%, 50 \%, 64 \%$ and $59 \%$, respectively. The concrete strengths in 7 -days were $66 \%, 75 \%$, $80 \%$ and $83 \%$, respectively. While in 14 -days were $87 \%, 91 \%, 93 \%$ and $93 \%$, respectively. Based on the results, the special curing of steam and elevated temperature have a significant effect to accelerate the early age concrete strengths as well as using chemical accelerator.

\subsection{High strength concrete}

The compressive strength of 3, 7, 14, and 28 days is shown in Table 5. The normalized percentage compressive strength to 28 days is given in Table 6 and illustrated in Fig. 6.

Table 5. Compressive strength (MPa)

\begin{tabular}{|c|c|c|c|c|}
\hline \multirow{2}{*}{ Specimens } & \multicolumn{4}{|c|}{ Ages of specimens } \\
\cline { 2 - 5 } & 3 Days & 7 Days & 14 Days & 28 Days \\
\hline HN & 19.09 & 33.54 & 43.86 & 51.60 \\
\hline HA & 30.09 & 37.37 & 43.19 & 48.53 \\
\hline HS & 31.92 & 38.96 & 42.25 & 46.94 \\
\hline HT & 32.28 & 37.29 & 42.29 & 45.47 \\
\hline
\end{tabular}

Where: $\quad \mathrm{HN}=$ High strength concrete under normal curing

$\mathrm{HA}=$ High strength concrete with accelerator

HS $=$ High strength concrete under steam curing

$\mathrm{HT}=$ High strength concrete under elevated temperature curing . 
Table 6. Normalized percentage of high strength concrete compressive test to 28 days

\begin{tabular}{|c|c|c|c|c|}
\hline \multirow{2}{*}{ Specimens } & \multicolumn{4}{|c|}{ Ages of specimens } \\
\cline { 2 - 5 } & 3 Days & 7 Days & 14 Days & 28 Days \\
\hline HN & $37 \%$ & $65 \%$ & $85 \%$ & $100 \%$ \\
\hline HA & $62 \%$ & $77 \%$ & $89 \%$ & $100 \%$ \\
\hline HS & $68 \%$ & $83 \%$ & $90 \%$ & $100 \%$ \\
\hline HT & $71 \%$ & $82 \%$ & $93 \%$ & $100 \%$ \\
\hline
\end{tabular}

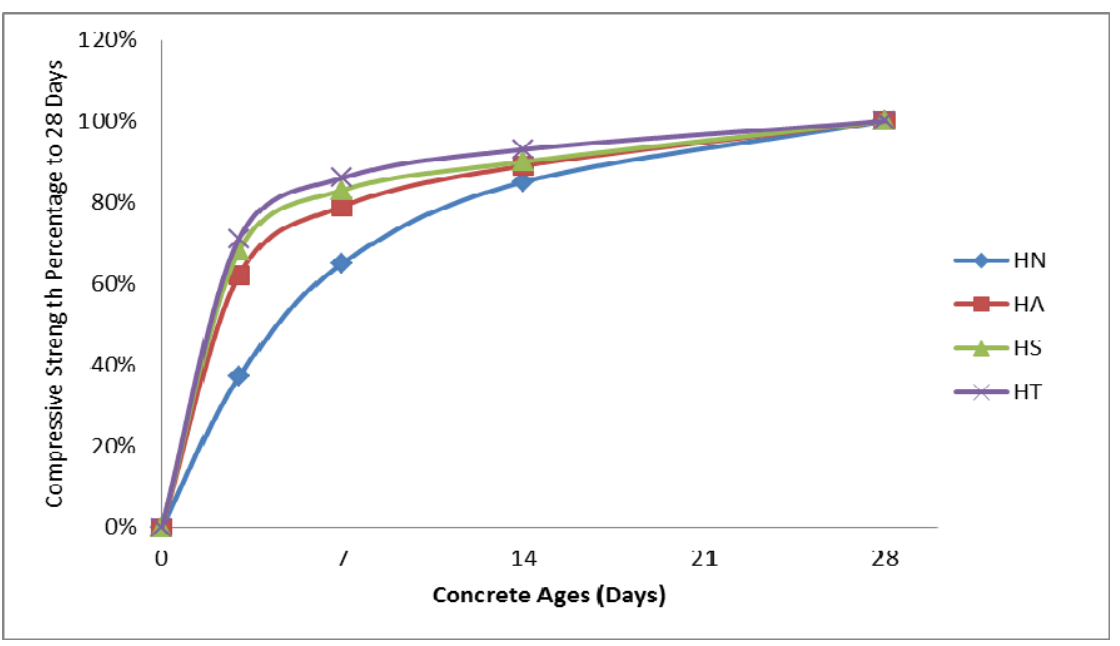

Fig. 6. Percentage of high strength concrete compressive test to 28 days

There are slightly different materials properties of high strength concrete compare to the normal strength concrete. In the age of 3 days, the highest accelerated concrete strength was the specimen under elevated temperature with the value of $71 \%$, almost twice compare to normal curing of $37 \%$. Concrete compressive strengths gained in 3-days were $37 \%, 62 \%$, $68 \%$ and $71 \%$, respectively. The concrete strengths in 7 -days were $65 \%, 77 \%, 83 \%$ and $82 \%$, respectively. And in 14-days were $85 \%, 89 \%, 90 \%$ and $93 \%$, respectively.

In general, the special curing of steam and elevated temperature have significant effect to accelerate the early age concrete strengths as well as using chemical addition accelerator. Therefore, in order to obtain the high early compressive strength of concrete, the special curing of steam and elevated temperature as well as using chemical addition accelerator are highly recommended.

\section{Conclusions}

The early compressive strengths gained under normal curing, chemical accelerator addition, steam curing, and elevated temperature curing can be concluded in the following.

- For normal strength concrete:

- 3-days were 12.12 MPa, 16.67 MPa, 18.94 MPa, and 17.78 MPa, respectively.

- 7-days were 20.51 MPa, 25.01 MPa, 23.68 MPa, and 25.01 MPa, respectively.

- 14-days were 27.03 MPa, 30.34 MPa, 27.53 MPa, and 28.02 MPa, respectively. 
- 28-days were 31.07 MPa, 33.34 MPa, 29.60 MPa and 30.13 MPa, respectively

Representing normalized percentage result of early age concrete strength to 28 days:

- 3-days were $39 \%, 50 \%, 64 \%$ and $59 \%$, respectively.

- 7-days were $66 \%, 75 \%, 80 \%$ and $83 \%$, respectively.

- 14-days were $87 \%, 91 \%, 93 \%$ and $93 \%$, respectively.

- For high-strength concrete:

- 3-days were 19.09 $\mathrm{MPa}, 30.09 \mathrm{MPa}, 31.92 \mathrm{MPa}$, and 32.28 MPa, respectively.

- 7-days were $33.54 \mathrm{MPa}, 37.37 \mathrm{MPa}, 38.96 \mathrm{MPa}$, and $37.29 \mathrm{MPa}$, respectively.

- 14-days were 43.86 MPa, 43.19 MPa, 42.25 MPa, and 42.29 MPa, respectively.

- 28-days were $51.60 \mathrm{MPa}, 48.53 \mathrm{MPa}, 46.94 \mathrm{MPa}$, and $45.47 \mathrm{MPa}$, respectively.

Normalized percentage result of early age concrete compressive strength to 28 days:

- 3-days were $37 \%, 62 \%, 68 \%$ and $71 \%$, respectively.

- 7-days were $65 \%, 77 \%, 83 \%$ and $82 \%$, respectively.

- 14-days were $85 \%, 89 \%, 90 \%$ and $93 \%$, respectively.

Grateful acknowledgement is addressed to the Post Graduate Program, University of Mataram for the financial support. Acknowledgement is also expressed to the Head of Civil Engineering Department, Faculty of Engineering, University of Mataram for facilities provided. Special thanks to Silvia, Wirandhini, Riyadi, and Yanuar for the support and assistance during experimental works.

\section{References}

1. Aercon, Technical Manual, Aercon AAC, Florida, USA (2014)

2. Civil Engineers Forum, Concrete curing method - advantage and limitation, Civil Engineers Forum Copyright (2016)

3. K. Tjokrodimulyo, Teknologi beton, Biro Penerbit Jurusan Teknik Sipil Fakultas Teknik UGM, Yogyakarta (2012)

4. A.M. Neville, J.J. Brook, Concrete technology, Second edition, Longman Group, London, United Kingdom (2010)

5. SNI 2847:2013, Persyaratan beton struktural untuk bangunan gedung, Badan Standardisasi Nasional Indonesia, Jakarta (2013)

6. S. Mindess, J.F. Young, Concrete, Second Edition, Prentice-Hall, Upper Saddle River, New Jersey (2003)

7. N. Angjaya, Perbandingan kuat tekan antara beton dengan perawatan pada elevated temperature dan perawatan dengan cara perendaman serta tanpa perawatan, J. Sip. Stat. 1, 3., Fakultas Teknik, Universitas Sam Ratulangi, Manado (2013)

8. V.I. Kullit, Pengaruh variasi suhu pada perawatan elevated temperature terhadap kuat tekan dan kuat tarik belah beton. J. Sip. Stat. 1, 7, Fakultas Teknik, Universitas Sam Ratulangi, Manado (2013)

9. Y. Nagao, K. Suzuki, Basic properties and utilization of steam-cured concrete using ground granulated blast-furnace slag, Nippon Steel \& Sumitomo Metal Technical Report, 109 (2015)

10. N. Nakajima, T. Maruyama, H. Koyama, S. Date, Effect of steam curing on initial strength development of mortar, Int. J. Eng. and Tech., 9, 6, December (2017)

11. A.A. Ramezanianpour, M.H. Khazali, P. Vosoughi, Effect of steam curing cycles on strength and durability of SCC: A case study in precast concrete, Const. Build. Mat. J, 49, 807-813, Elsevier (2013). 